* FORTHCOMING IN THE JOURNAL OF NONPROFIT AND PUBLIC SECTOR

MARKETING

\title{
EXPLORING CONSUMER'S NEEDS AND MOTIVATIONS IN ONLINE SOCIAL LENDING FOR DEVELOPMENT
}

\author{
Robert Mittelman \\ Ph.D. Candidate \\ Sprott School of Business \\ Carleton University \\ 1125 Colonel By Drive \\ Ottawa, ON CANADA \\ K1S 5B6
}

Phone: Tel: (613) 520-2600 x6704

Fax: 613-520-4427

Email: robert.mittelman@carleton.ca

\author{
José I. Rojas-Méndez* \\ Associate Professor, International Business \& Marketing \\ Sprott School of Business \\ Carleton University \\ 1125 Colonel By Drive \\ Ottawa, ON CANADA \\ K1S 5B6
}

Phone: 613-520-2600 x8014

Fax: 613-520-4427

Email: jose.rojasmendez@carleton.ca

* Corresponding author

\section{ACKNOWLEDGEMENTS}

We are grateful to John B. Ford for his helpful comments on an earlier draft of this paper. We would also like to acknowledge the financial support of the Carleton Centre for Community Innovation (3Ci) in creating the custom software used for the data collection. 


\title{
EXPLORING CONSUMER'S NEEDS AND MOTIVATIONS IN ONLINE SOCIAL LENDING FOR DEVELOPMENT
}

\begin{abstract}
This study is the first in exploring the needs and motivations of those who participate in the social phenomenon of Online Social Lending for Development (OSL4D). OSL4D represents a new form of charity support behaviour that has raised numerous important theoretical issues about the evolving nature of charitable giving and the motivation of its participants. A model of lending behavior is proposed. Using data from Kiva.org, the authors consider the different theoretical needs and motivations to participate in social lending and, through content analysis of 1,283 consumer statements from the members of the Team Canada lending team about the reason they lend, conclude that OSL4D consumers are principally intrinsically motivated to make a small difference in the lives of the working poor. Managerial conclusions are offered as well as ideas for future research.
\end{abstract}

Keywords: charitable giving, donor behaviour, social lending, Kiva.org, needs, motivations, intrinsic, extrinsic 


\section{INTRODUCTION}

Asking the question why consumers make the choices they do when it comes to charitable giving has interested a diverse group of research scholars from management, marketing, economics, psychology, and sociology to name but a few of the many applicable

disciplines (Sargeant \& Woodliffe, 2007b). Research that contributes to explain this phenomenon in the marketing sub-discipline of consumer behavior has been scant, and most of the time has been focused on donor behavior as the outcome of a decision making process, or as a way to increase efficiency of fundraising techniques (Jas, 2000).

The word motivation is coined from the Latin word "movere", which means to be moved to do something (Ryan \& Deci, 2000). Motivation is defined as an internal drive that activates behavior and gives it direction. For many charities and non-profit organizations, faced with a growing demand for their services, increased competition from other organizations for scarce financial resources, and reduced support from government, the need to understand the motivation of donors is of crucial importance (Sargeant, West, \& Ford, 2004; Bendapudi, Singh, \& Bendapudi, 1996). A new, innovative model of charitable giving has emerged which not only challenges the existing understanding of donor motivation but the entire donor/recipient paradigm.

This study introduces the emerging concept of Online Social Lending for Development (OSL4D) and explores the needs and motivations of those who participate in it. OSL4D is a social phenomenon that has materialized at the intersection of the consumer behaviour, nonprofit management, information technology, and international development disciplines. It has raised numerous important theoretical issues about the evolving nature of charitable giving, the motivation of consumers, as well as the portrayal of the working poor in developing countries. In 
addition to introducing the concept of OSL4D to consumer behaviour research, we proposed a theoretical model of lending behavior. The empirical portion of this study is an examination of the motivations of those who participate in OSL4D. The sample contains 1,283 consumer statements from members of the Team Canada lending team on Kiva.org, an American-based non-profit organization that facilitates OSL4D, as they complete the open-ended phrase "I loan because...". .

\section{ONLINE SOCIAL LENDING FOR DEVELOPMENT}

At the core of OSL4D is the idea that the internet can facilitate small-scale lending by socially-minded investors from around the globe to micro-entrepreneurs in developing countries in an effort to alleviate poverty. This is accomplished using one of a number of competing websites where lenders (or "consumers of charitable giving") are given the choice of who they would like to support by making a small loan after reviewing an entrepreneur's profile, which includes information on their particular story, their family and economic situation, as well as the proposed use of the funds.

For example, a potential lender enters an OSL4D website where they are able to review the profiles of hundreds of working poor in need of funding to start or grow their business. The lenders could read about a baker in the Dominican Republic who needs $\$ 220$ to buy a new flour mixer, a group of used clothing sellers in Uganda who need $\$ 330$ each to buy more clothes, a pig farmer in the Philippines who needs $\$ 150$ to buy livestock, or a restaurateur in Peru who needs $\$ 725$ for new tables and chairs. A loan made online to the borrower of the lender's choice is distributed by a local microfinance partner and used to run a small business. The lenders decide how much to lend, whether the total amount of the requested loan or just a portion. When the 
total amount of the loan is raised on the OSL4D site, it gets distributed in the developing country. Every month, as the instalments on the original loan are paid back locally, the lender receives their share paid back into their online account. Upon repayment, the lender is free to lend again to another deserving entrepreneur in the same or different country. It is a powerful and sustainable approach to empower someone to lift themselves out of poverty.

OSL4D is a new conceptualization of charitable giving, not as a traditional donation but as a loan. It is the provision of a hand-up instead of a hand-out. The consumer is transformed from a passive, financial donor with little choice or knowledge as who specifically their contribution helps, to an active and invested participant in enabling a chosen individual's efforts at improving their quality of life through entrepreneurship. Simultaneously, the perception of the borrower in the developing country is transformed from a helpless recipient of aid to a micro entrepreneur, active in their own efforts at breaking the cycle of poverty. It is a move away from traditional sponsorship of the poor by the rich used by many charities towards a new dignified model of peer-to-peer empowerment. As such, engagement with the lender by those organizations facilitating OSL4D may not use the same approaches and theories traditionally used by charitable organizations to raise funds.

The current conceptualizations of either charitable giving may be insufficient to describe behaviour in this area, thus calling for specific research. Studies have shown that not all types of charity helping behaviours should be treated as equivalent (Pearce \& Amato, 1980; Smithson \& Amato, 1983; Drollinger, 2010). Drollinger (2010) highlights the differences in behaviour between such diverse charity helping behaviour such as donating blood and donating money. These behaviours, much like lending money and donating money, are very different and deserve consideration as such. Peloza and Hassay (2007) introduce a comprehensive typology of charity 
support behaviours in which OSL4D could not be properly placed. In their typology, the options for different form of charitable financial contributions include either a donation or a gift (Peloza \& Hassay, 2007); OSL4D is neither. Theory does not yet exist to explain the consumer's behaviour or participation in the OSL4D process. In this pre-paradigmatic stage, the theories and models still need to be built to explain the needs and motivations and behaviour of consumers in OSL4D, in other words, the why and the how of this emerging phenomenon. This study examines the why and responds to Peloza and Hassay's (2007) call for more research on non-conventional forms of charity support behaviour.

\section{LITERATURE REVIEW AND THEORETICAL FRAMEWORK}

Focusing on an individual's reason for social lending involves the domain of motivation theory. Ryan and Deci (2000) argue that motivation is hardly a unitary phenomenon because individuals not only have different levels (i.e. amounts) of motivation but also different orientations (i.e. kinds of motivation). In line with this, motivation theorists distinguish two types of motivation: intrinsic and extrinsic (Deci, 1975; Deci \& Ryan, 1985). In general, they explain that a person is described as being intrinsically motivated if he or she embraces an activity for personal enjoyment and satisfaction. In this case, motivation is driven by an interest or enjoyment in the task itself, and exists within the individual rather than relying on any external source. In addition, intrinsic motivation also exists in the relation between individuals and activities (Ryan \& Deci, 2000). Frey and Goette (1999) posit that intrinsic motivation may play an important role in institutions characterized by personal relations such as non-profit organizations, where it is expected that volunteers experience satisfaction from the action in 
itself. This type of motivation has been recognized as a critical element in individuals' cognitive, social, and physical development (Ryan \& Deci, 2000).

Alternatively, extrinsic motivation comes from outside of the individual, or whenever an activity is done for the interest of obtaining a separable outcome. Thus a person who is extrinsically motivated will perform an activity based on his/her interest in receiving compensation or recognition by participating or supporting a particular action. For instance, in the context of charities, donors may be attracted by the social recognition derived from donations (Meier \& Stutzer, 2008), the opportunity to increase his/her social network (Meier \& Stutzer, 2008; Prouteau \& Wolff, 2004), or even for a more utilitarian motivation such as receiving tax benefits for their contribution (Russell III, 2008; Auten, Sieg, \& Clotfelter, 2002; Randolph, 2005).

Further to the previous classification, Self-Determination Theory (SDT; Deci \& Ryan, 1985) proposes that there are several types of extrinsic motivations varying from impoverished forms to those that represent active, agentic states. Extrinsic motivation may vary in the relative autonomy: some extrinsic motivators entail some personal endorsement and a feeling of choice, and others may involve mere compliance with an external control. More recently, Ryan and Deci (2000) offer the related Organismic Integration Theory (OIT) to illustrate the taxonomy of human motivation in a kind of continuum from the point of view of the perceived locus of causality. First, they identified the regulatory style of amotivation, which encompasses individuals not valuing an activity, not feeling competent to do it, or not believing it will yield a desired outcome. In this case, the perceived locus of causality is impersonal. Second, they classify extrinsic motivation in four types of regulatory styles with different associated processes: external regulation (salience of extrinsic rewards or punishments, compliance, 
reactance), introjections (ego involvement, focus on approval from self or others), identification (conscious valuing of activity, self-endorsement of goals), and integration (hierarchical synthesis of goals, congruence). For these four styles, the perceived locus of causality moves gradually from external in the case of "external regulation" to internal for "integration". Lastly, they include the intrinsic motivation which is absolutely internal in its locus of causality.

To date, there has been relatively little research done specifically in social lending for development, either from academia or industry. From industry, Hulme and Wright (2006) call OSL4D "a direct response to social trends and a demand for new forms of relationship", and Bonbright, Kiryttopoulou, and Iverson (2008) say that it is turning donors into real investors in sustainable social change rather than providers of occasional short-term relief. Ashta and Assadi (2010) examine the role of the internet and Web 2.0 technologies in OSL4D and conclude that the relationship between the borrower and lender is not as "peer-to-peer" as it claims to be. Lenders have been shown to prefer individual borrowers over groups (Galak, Small, \& Stephen, 2010; Ly \& Mason, 2012), to lend to those who are more like themselves (Galak et al., 2010), as well as to women over men and loans with shorter repayment times (Ly \& Mason, 2012). Lender motivation has yet to be addressed in the literature. Thus, the objective of this paper is to improve the understanding of the influence of intrinsic and extrinsic motivations on online social lending for development. Intrinsic motivation and extrinsic motivation are seen as time and context dependent, so the same activity can be intrinsically or extrinsically motivating for different people.

In the following sections we consider the different theoretical motivations to participate in social lending, a description of Kiva, which is the organization that inspires our work, the 
methodology including a description of the data, and the method of analysis and results. A discussion of the findings, limitations to the study, and future research concludes the paper.

\section{A THEORETICAL MODEL OF LENDER BEHAVIOR}

In studying the behavior of OSLAD participants, two of central questions are why and how. The why can be examined by looking at the various needs and motivations that charitable giving can address. The how can be examined by looking at the charitable giving alternatives and the decision criteria used by lenders. Here we present a proposed model of lender behavior.

\section{Insert Figure 1 - Model of Lender Behavior}

\section{Needs}

While one of the major goals of marketing is the satisfaction of consumer needs, the nonprofit marketing and charitable giving literature has yet to comprehensively explore the underlying needs that financial donations address. Sokolowski (1996) suggests two causal models of human behavior that help explain why people give, an attitudinal model and a microstructural model. The attitudinal model suggests that charitable giving can be explained by two types of motives: value-rational motives that aim at benefiting others; and the rational pursuit of self-interest (Sokolowski, 1996). In terms of human needs, we categorize these two types of motives as: the need to express Love for Humanity and need to obtain Personal Happiness.

The need to express Love for Humanity comes from the foundation of philanthropy. The word philanthropy, often interchangeably used with charitable giving, itself means 'love of mankind' (Sulek, 2010). It comes from the classical Greek word philanthrôpía; a compound 
word composed of philê, meaning "love" and anthrôpos, "humankind" (Sulek, 2010). This 'love of mankind' and the desire to help the needy can be found as central tenants in major religions like Christianity, Hinduism, Islam, Judaism, and Buddhism (Ranganathan \& Henley, 1997). Alternatively, the need to obtain Personal Happiness is based on consumer choice theory which recognizes a consumer's desire to maximize their personal utility from the purchase of good and services in the marketplace (Sheth, Newman, \& Gross, 1991).

\section{Motivations}

There is an acknowledged multiplicity of motivations for making a donation within the charitable giving literature (e.g. Bendapudi et al., 1996; Burnett \& Wood, 1988; Sargeant \& Woodliffe, 2007b). Researchers have identified various complementary and/or competing motivations including altruism, egoism, empathy, sympathy, guilt, social justice theory, tax benefit, religious obligation, prestige, and the desire to make a difference.

\section{Altruism and Egoism}

Altruism or "other-benefit" involves a person's behavior that voluntarily benefits a needy person without the expectation of reward, even at the expense of a person's own welfare (Bendapudi et al., 1996). The basic need to help others has been argued to be the strongest motivating force in giving to charity (Guy \& Patton, 1989). There has been much debate about whether or not a purely altruistic motive truly exists (Batson, 1990; Andreoni, 1990). Batson (1990) posits that an altruistic motive would have the relief of other's suffering as its ultimate goal and that the resulting self-benefit for the giver is an unintended consequence. Humanitarian issues, such as the focus on poverty alleviation in the developing world, are ever more central to 
consumers and altruism offers a theoretical foundation for understanding these motivations that consumers may possess (Powers \& Hopkins, 2006).

Egoism or 'self-benefit' reflects a person's motivation where they primarily give because the act of giving brings about benefits to the donor first (Harbaugh, 1998). When egoism is the primary motivation, the ultimate goal of giving is the benefit that the donor receives while the relief of someone else's suffering is merely the instrument used to achieve it (i.e. produces a pleasurable feeling) (Batson, 1990). This has also been referred to as warm-glow giving (Andreoni, 1990).

\section{Empathy and Sympathy}

Gruen and Mendelsohn (1986: 609) explained the difference between empathy and sympathy as follows:

"Empathy as an emotional response entails a correspondence of positive or negative tone, or a matching of affect, between an observer and the person being observed. Sympathy, on the other hand, does not involve a reproduction of the emotion perceived in another but is, rather, a response of compassion or concern evoked by the plight of another."

Both states illustrate an emotional concern for the wellbeing of others, however with sympathy one feel for the person while with empathy one feel with the person. As such, empathy requires a deeper understanding of the particular context of the other person. As consumers travel more and have experiences in other countries or learn about the living conditions in the developing world through the Internet or the media, awareness and understanding of the plight of those stricken by poverty grows (Nijssen \& Douglas, 2008). Sympathy requires less knowledge of the particular contexts but maintains a personal connection. People are more empathetic 
towards members of their in-group, who are similar to them, or where they have been close to someone else's personal experience with misfortune (Small \& Simonsohn, 2008).

\section{Guilt}

Guilt is another motive often mentioned in the charitable giving literature (Huhmann \& Brotherton, 1997). Feelings of guilt are the result of a person holding the belief or knowledge that they have violated some social custom or ethical principle (Basil, Ridgeway, \& Basil, 2006). The recognition of differences in the well-being between two people can cause feelings of guilt and can spur an individual on to help those less fortunate (Basil et al., 2006). Guilt can be separated into three types: reactive, anticipatory, or existential (Huhmann \& Brotherton, 1997). Reactive guilt implies that the person has violated their own standard of acceptable behaviour whereas anticipatory guilt occurs when a person is considering violating said standard of behaviour (Coulter, Cotte, \& Lunt Moore, 1999). Existential guilt is a result of the aforementioned recognition in differences between the individual and those less fortunate. Huhmann and Brotherton (1997) posit that charities often use feelings of existential guilt to drive donations to relieve the suffering of victims of poverty.

\section{Social Justice}

The motivation to make a charitable contribution can also be influenced by a person's desire to believe in a just world (Lerner, 1975). The contention is that for people to function in their environment they must believe that their 'world' is a just place (Miller, 1977). Therefore if people witness undue suffering or inequality, they would be motivated to re-establish 'justice' (Miller, 1977). This just world might represent either an equality of opportunity or an equality of 
result (Basil, 2007). The equality of opportunity speaks to everyone having the same chance at success, happiness, money, etcetera, but what they do with that opportunity is up to them. Having the same opportunities is 'just'. Equality of results, on the other hand, speaks to the lack of disparity among individuals' actual situations (Basil, 2007). Donors motivated by social justice would be more likely to support those who had little or no responsibility for their situation as opposed to supporting those who may have caused their own suffering (Bendapudi et al., 1996). An example of this difference amongst those who are motivated by social justice may be the support demonstrated for those suffering from breast cancer as opposed to those suffering from lung cancer. Social justice theory would motivate support for breast cancer as the sufferer bears no responsibility in contracting the disease whereas lung cancer may be the result of the individuals smoking habit and thus are partially responsible for their own situation.

\section{Tax Benefits}

From a utilitarian point of view, that charitable contributions may be used against a donor's income to lower income taxes may be a motivation for some donors. This motivation has been studied with respect to incomes levels (Auten et al., 2002; Randolph, 1995) as well as with respect to financial planning for both the afterlife as well as during the donor's lifetime (Russell III, 2008). This compensatory financial return for a donation is an important motive for charitable giving however it must be noted that, in a strictly financial sense, not making a charitable donation will leave the donor in a better position (Sargeant \& Woodliffe, 2007b).

\section{Religious Commitment}


The examination of religious commitment and motivations may complicate the general study of charitable giving. While it may be tempting to ignore these motivations and reduce the complexity of the study, religious donations represent the largest and most widespread form of charitable giving (Statistics Canada, 2009). Two main theoretical approaches attempt to incorporate religious motivations into models of charitable giving: (a) salvation motivation or motivation for the afterlife; and (b) motivations for the here and now. Salvation motivation extends the reciprocal benefits of giving to charity to include afterlife (Azzi \& Ehrenberg, 1975; Hrung, 2004). When considering the here and now, Iannaccone (1998) posits that expectations for the afterlife are replaced with benefits such mutual aid, social support, group identity, moral instruction and other more tangible results.

\section{Prestige}

Prestige is a motive for charitable giving when the donor is motivated by the recognition their contribution brings (Sargeant \& Woodliffe, 2007b). The benefit from the donation, while it is a self-benefit, is not the same as the warm-glow motivation as described by Andreoni (1990) and Harbaugh (1998). Prestige is only acquired when the donation is made public (Harbaugh, 1998). The prestige motive has been shown to be very prevalent among young professional men who search out the public recognition for their donations through invitations to exclusive galas and black tie events (Kottasz, 2004).

\section{Desire to make a difference}

Duncan (2004) describes the donor who personally wants to make a difference as an impact philanthropist. The motivation of an impact philanthropist is such that he may refuse to 
pay for organizational overhead costs or contribute to a general fund. He would prefer to target his donation to a very specific person or part of the process as this would increase the overall impact of his contribution. The desire to make a difference and impact philanthropy is one of the newest motivations to be identified and as a construct lacks empirical testing (Sargeant \& Woodliffe, 2007b). It seems that this motive should be intimately related to OSL4D.

Weick (1984: 40) argues that the large scale upon which social problems are conceived often stifles action because "the limits of bounded rationality are exceeded and arousal is raised to dysfunctionally high levels". He posits that by recasting large problems into smaller, more manageable problems, people can identify opportunities and solutions that may achieve 'small wins' (Weick, 1984). For example, eradicating global poverty may seem insurmountable and a contribution of $\$ 25$ or $\$ 100$ may seem insignificant. Even a $\$ 1$ million contribution will not solve this social problem. However, if a small donation can help one person, while that may seem unimportant, once a small win like this is accomplished, momentum begins to build for another small win (Weick, 1984). For an impact philanthropist who wants to make a difference, the concept of small wins is a strategy worth supporting.

By using the Organismic Integration Theory (OIT, Ryan \& Deci, 2000) as a framework, Table 1 shows the different motives for charitable giving found in the literature categorized by their perceived locus of causality.

Insert Table 1 Organismic Integration Theory (OIT) Taxonomy of Motivations

The perceived locus of causality from the OIT presents an excellent differentiator between the types of motivations and matches with the two proposed needs met from charitable giving. The need to express Love for Humanity fits with the internal locus of causality and therefore with the following motives: Altruism, Desire to Make Difference, Empathy, Existential 
Guilt, Religious Commitment, Sympathy, Social Justice. Conversely, the need for personal happiness matches with the external locus of causality and therefore with the remaining motives: Anticipatory Guilt, Egoism, Prestige, Reactive Guilt, Tax Benefit.

\section{Insert Table 2 Needs and Motivations}

\section{Charitable giving alternatives}

Peloza and Hassay (2007) highlighted two forms of charity support behavior that are based on the transfer of funds to a charity: financial contributions and purchasing. These choices can then be further divided amongst the intended recipient of the contribution; either an individual or an organization. Any consumer interested in financially supporting international development efforts must choose between a) supporting an institution or a person, and b) making a donation or making an investment. For those interested in supporting an institution via donation, there are traditional charities and for those interested in supporting an individual via

donation, there are sponsorship programs. For those would rather make an investment or a purchase, at the institutional level, there are socially responsible investment funds focused on emerging markets or socially responsible shopping choices such as buying fair trade products. Before OSL4D, nothing existed in the personal and sustainable quadrant. Figure 2 clearly indicates how the value propositions for consumers in each of the quadrants are different and why OSL4D must be treated differently. The approaches used by organizations in each of the quadrants are as different as the value they provide to the consumers.

Insert Figure 2 Lender Value Proposition

\section{Decision criteria}


We propose that there are three main steps in the decision criteria in OSL4D: choosing a cause to support, choosing a charity within that cause, and choosing a borrower from that charity.

There are numerous choices of social cause from which to choose of which we have only listed a few. In OSL4D, the main focus in on poverty alleviation through entrepreneurship. However, OSL4D organizations are beginning to expand into supporting home improvements, education, and health initiatives as other areas of focus.

Then the lender must choose the charity or OSL4D organization to support. Assadi and Hudson (2010) examine the marketing mix of eight online social lending websites: Kiva, Fynanz, LendingClub, Microplace, MyC4, Prosper, VirginMoney, and Zopa. From this list, only three (Kiva, Microplace, and MyC4) are identified as having humanitarian goals of poverty alleviation through entrepreneurship. These organizations can be assessed by a number of factors some of which we have listed in the model (see Figure 1). The first two factors outlined in the model, Choice of Cause and Choice of Charity, apply to any charitable giving situation. However, in OSL4D, there is a further set of decision criteria, the Choice of Borrower.

The OSL4D supporter must choose which borrower to whom they will lend their money. Based on the extant literature (e.g. Galak et al. 2010; Ly \& Mason, 2012) and the authors' understanding of OSL4D, we suggest the following 10 criteria from which a lender might choose a borrower: country, gender, age, language, commercial activity, marital status, number of children, picture, name, and story.

\section{INTRODUCTION TO KIVA.ORG}


Discovering, appreciating, and applying factors that motivate someone to give philanthropically are a fundamental responsibility of fundraising practitioners. While endeavouring to find out what motivates a person to give, those involved in the process will begin to build the context around which that person may be solicited to invest philanthropically in a cause. The role a fundraiser plays as a conduit between needs and interests is vital to successfully complete the philanthropic transaction to the full satisfaction of both the donor and the organization.

Founded in 2005 by Matt Flannery and Jessica Jackley, Kiva (http://www.kiva.org) is an American non-profit organization that allows individuals, with as little as \$25 USD, to lend money to micro-entrepreneurs around the world via the Internet and local microfinance institutions. Inspired by the Grameen Bank, this model aims to provide small loans for entrepreneurial activities for people in developing countries who are unable to access credit and loans from mainstream financial institutions (Flannery, 2007). Kiva's stated mission is to 'connect people through lending for the sake of alleviating poverty' (Kiva, 2010). Kiva.org is headquartered in San Francisco, California.

Kiva.org currently connects more than 1 million users from around the world who have lent more than $\$ 287,000,000$ USD to approximately 734,000 borrowers in 61 countries (Kiva, 2012). The average Kiva lender has made 8 loans and the average total amount loaned per Kiva lender is \$263, while the average Kiva borrower requires a loan of \$389 (Kiva, 2012).

Flannery (2007) claims that when it came to lenders, he wanted to appeal to their "interests, not their compassion" (p. 40). Flannery goes on to say that "Lenders show unambiguous preferences according to region, gender, and business type. Africans first, women first, and agriculture first. A female African fruit seller? Funded in hours. Nicaraguan retail 
stand? Funded in days. A Bulgarian taxi driver? Funded in weeks" (Flannery, 2007). According to Gerard Neimira, Kiva's Customer Service Manager, "some see themselves as a patron, in the spirit of the child-sponsorship model. Others see themselves as a business partner. Most just want to help in some way" (Carlman, 2010: 98).

Kiva lenders are presented with an ever-changing array of alternatives to who they can lend. New loans are posted throughout the day as they are uploaded from partners around the world and loans are removed from the site as soon as they are fully funded. Lenders can search for loans they wish to fund by a number of criteria including: gender of the borrower, country of the borrower, borrower's business type, group or individual loans, loan amount, amount remaining, repayment terms, expiring soon, and newest loans. Potential lenders are also free to search all loans viewing the borrower's picture and reading their intended project.

\section{METHODOLOGY}

\section{Data Source and Description}

Kiva lenders create online, public profiles when they sign up to become a lender. Only a username is required and any additional information is strictly voluntary. Some of the options available when creating a profile include identifying the donor's full name, where is he or she from, uploading a picture of him/her, some interesting information about him/her, and the opportunity to complete the sentence "I loan because". The "I loan because" statement is used in this study as a proxy for their motivation in participating in the OSL4D process.

In December 2011, we downloaded the public lender profiles of the 3,120 members of the Team Canada lending team (see Table 3). A lending team is a group of Kiva lender accounts voluntarily affiliated with each other based on some common bond; in this case all team 
members claimed to be either Canadian or living in Canada. Of these 3,120 members, 1,299 profiles contained an "I loan because statement" of which 1,283 were acceptable for analysis. Only statements made in English were selected as well as those that expressed a coherent thought. The final sample of 1,283 statements represents $41 \%$ of all Team Canada members.

Insert Table 3 Team Canada Profile

\section{Method of Analysis}

To accomplish our research objective we conducted a content analysis of the "I loan because" statements. This method has proven to be a valuable technique for understanding consumer motivations, specifically with respect to social issues (Schneider, Loeber, Janßen, Roehrig, \& Solle, 2010; Essoussi \& Zahaf, 2008).

\section{RESULTS AND ANALYSIS}

The literature predicted various motivations for consumers' participation in the OSL4D process. Before exploring the actual motives for social lending, we analyzed the words used by lenders when completing the sentence "I loan because". Figure 3 is a word cloud or a visual representation of the word frequency in the "I loan because" statements where greater prominence is given to words that appear more frequently in the source text ${ }^{1}$. A total of 2,438 different words were used by the 1,283 lenders.

\section{Insert Figure 3 I loan because Word Cloud}

The most popular words used in the statements were variations of the following words (i.e. in the form of verbs, adjectives, nouns, etc.): help (523 times); can (333 times); people (295

\footnotetext{
${ }^{1}$ To create a word cloud on Wordle.net, the process is fairly simple: users go to http://www.wordle.net, paste the selected text into the text box or enter the URL of any blog, blog feed or other web page, hit the 'Submit' button, and get a word cloud. The initial cloud is generated with randomized visual parameters but the user then has the ability to customize according to font, color, and layout. Some common words have been removed from the cloud, such as 'can' but were included in the analysis.
} 
times); life (257 times); make (238 times); others (207 times); world (190 times); want (187 times); give (164 times); way (151 times); believe (136 times); difference (104 times); small (101 times); better (98 times); and loan (98 times). Despite Kiva's stated mission to 'connect people through lending for the sake of alleviating poverty' (Kiva, 2010), the word connect does not appear in any of the 1283 motivation statements. This preliminary analysis gives an objective approximation to the types of motives people have when lending money for social development. Choosing some of the most popular words would suggest that Kiva lenders loan because they believe they can help people, want to make the world better, to make a difference in the lives of others, and a loan is small way to do so. The words seem to indicate an intrinsic motivation on the part of the Kiva lender. After reviewing the extant literature, we randomly read approximately $10 \%$ of all narratives for the question "I loan because ..." and developed our list of 12 potential motives or categories for OSL4D: Altruism (other benefit); Egoism (selfbenefit); Empathy (feel with the person); Sympathy (feel for the person); Anticipatory Guilt (consider violating standard of behaviour); Reactive Guilt (has violated standard of behaviour); Existential Guilt (recognize the difference between individual and those less fortunate); Social Justice (fairness); Tax Benefit (financial compensation); Religious Commitment (duty to community or higher power); Prestige (recognition); and Make a Difference (impact, small wins).

To enhance coding validity the open-ended statements were assessed by two different coders. The first coder, being one of the authors, coded all of the 1,283 statements voluntarily expressed by the lenders. Even though the codes (i.e. motives for lending) were mutually exclusive, in some cases it was possible to classify the statements into more than one code. Therefore, the coder was instructed to look for the most relevant motive comprised in each 
statement. After the first coder finished the categorization process of the motives expressed by the Kiva lenders, a second coder used the coding schema developed to independently code again all of the 1,283 statements. The second coder was not familiar with the OSL4D literature, and was only superficially informed about the study's purpose.

Inter-coder agreement on categorizations was initially $79 \%$ and Cohen's kappa, which excludes pure chance agreement between coders (Grayson \& Rust, 2001), was 0.74 (range from $0=$ chance level, $1=$ perfect agreement). This kappa coefficient indicates substantial agreement (based on the interpretation guide offered by Landis \& Koch [1977]). Finally, all disagreements between the two coders were resolved by discussion with the other author not involved in the initial categorization process, and subsequent consensus was achieved.

Content analysis reveals that all twelve of the motivations established in the literature were found in the list of "I loan because" statements (see Table 2). Despite the fact that OSL4D is an innovation in both the nonprofit and charity marketplace and challenges the traditional relationship between the donor, the organization, and the recipient, the authors were able to classify all of the consumers' motivations for lending within the recognized charitable giving motivations.

\section{Insert Table 4 OSL4D Lender Motivations}

The most popular motive for participating in OSL4D was also the newest motive to be identified in the academic literature, the desire to make a difference. A total of 442 of the 1,283 consumer statements (34\%) were found to be motivated by the impact of their donation and the small wins that result from OSL4D loans. Examples of these statements include "the impact of my small donation has the power to be life changing" or "a little money can make such a big 
difference in the lives of families around the world". This is consistent with the limited research on OSLAD which claims that OSL4D is a "direct response to social trends and a demand for new forms of relationship" (Hulme \& Wright, 2006).

While Kiva's strategy is to appeal to their consumers' interests and not compassion (Flannery, 2007), many lenders appear to be motivated by various emotional states. The second most popular motive was altruism with 239 statements (19\%) that contained expressions of altruistic intentions on the part of the lender. Examples of altruism include statements about caring ("I loan because I care") and helping ("I loan because I want to help people"). Both the make a difference and altruism motivations are categorized as being pure intrinsic motivations. When revisiting the Organismic Integration Theory taxonomy of types of motivations (see Table 1) and placing the OSL4D lender's motivation in the appropriate categories (see Figure 4), a pronounced pattern emerges as the continuum is heavily weighted towards the right side indicating that the majority of motivations of OSL4D lenders are internalized or intrinsic.

\section{Insert Figure 4 OSL4D Lender Motivation by OIT Taxonomy}

Following behind altruism is the social justice motivation with 198 statements (15\%) such as "We're all connected and people deserve a chance to make a better life for themselves and their families regardless of where they are born"[emphasis added]. This result is in line with a study by Sloane, Baillargeon, and Premack (2012) who found that even two year old infants "already have rich and subtle expectations about how individuals should distribute resources" (p.203) and context-sensitive beliefs relevant to fairness.

The analysis also revealed a total of 146 statements containing various elements of guilt (12\%) and, more precisely, existential guilt (138 of the 146 guilt statements). Examples of these statements include "I have way more than I need", "I should", and "I won the lottery by being 
born in Canada. It's the right thing and my obligation to help others". There were only 7 mentions of anticipatory guilt (1\%) such as "I loan because the money will just rot in my bank otherwise" and only a single mention of reactionary guilt, "By loaning I justify my large collection". As the relationship between lender and borrower (or classically donor and recipient) in OSL4D becomes more of an exchange between equals, the feelings of guilt from having more than your peer and wanting to share with them are becoming more pronounced.

There were much fewer mentions of egoism (8\%) or sympathy (6\%). Only $3 \%$ of statements contained references to religious commitment or motivations. Many of these statements contained Bible verses, religious expressions, or references to blessings they have received. While religious commitment may still motivate many donors, this motivation may be stronger and more explicitly expressed when making contributions directly to religious organizations; Kiva is a secular organization with no religious or political affiliation. There were very few mentions of empathy (3\%), prestige $(1 \%)$, or tax benefit $(0 \%)$. The null result is not surprising as the majority of the funds on Kiva are loans and returned, therefore not a traditional charitable contribution and thus there is no tax benefit. While there is the opportunity to give directly to Kiva to support organizational operations and not to an entrepreneur, Kiva is an American organization and Canadians would not receive any tax benefits from their donation.

\section{MANAGERIAL IMPLICATIONS}

For nonprofit marketing managers, the results of this study offer a number of important implications. Within their own existing group of charitable donors, nonprofit marketers need to 
understand the motivations of their supporters and match them with the appropriate charitable giving alternative.

Firstly, on its own, no one giving alternative is better than the other. It is only when it is paired with the motivation of the donor that can we tell if the campaign will be successful. We can surmise that part of Kiva's success rests with this synergy between their offering, the loan, and the motivation of a majority of their supporters, the desire to make a difference. Kiva has managed to provide their supporters and OSL4D participants with a value proposition that was previously unavailable within the charitable giving space; a sustainable and personal alternative. Furthermore, Kiva is able to effectively communicate the impact of the loan as well as provide the necessary feedback (in terms of the monthly loan repayments) to reinforce the small win that results from the donor's participation. A small wins strategy creates a positive feeling for the donor which would suggest relending of the funds and continued participation with Kiva. From this we can discern that Kiva's success in attracting new supporters rests on the following three key characteristics of OSL4D: sustainable, personal, and impactful.

This idea of a sustainable, personal, and impactful offering is by no means limited to microfinance. While for some it would be impractical and inappropriate to copy Kiva's method of loans or peer-to-peer selection, the core elements of the strategy can be extended to other causes. By examining their own organization and social cause, nonprofit managers can look for a sustainable, personal, and impactful alternative that will appeal to the motivations of a new group of charity supporters.

Secondly, there seems to be a large amount of congruence between OSL4D and the lenders' personal values. According to Ryan and Deci (2000), this kind of internalization by 
lenders, or donors in the general charitable giving space, indicates a sense of belongingness, connectedness, and relatedness to the goals of the organization and to those they serve. This conclusion is supported by Sargeant and Woodliffe (2007a) who show that shared values lead to active commitment which leads to loyalty in the donor-charity relationship. This is further confirmed in the consumer behavior literature where the Commitment-Trust theory (Morgan \& Hunt, 1994) shows that shared values between exchange partners leads to increased trust and personal commitment which in turn results loyalty in consumer behavior. At a time when charities and nonprofit organizations are competing for scarce financial resources, this kind of alignment between organizational and donors' personal values will prove critical in retaining these lenders and getting them to lend again.

\section{LIMITATIONS AND FUTURE RESEARCH}

There are a number of limitations to this study. Firstly, the analysis of motivations is based on one organization. Would the motivation of lenders from other facilitators of OSL4D be similar? Secondly, the analysis is based on a group of lenders from one country. As a response to this study, more studies involving lenders in different geographical regions would be useful to determine whether lender motivations change based on nationality or cultural differences. Furthermore, the analysis of motivation is based on one written statement. Future qualitative and quantitative research should involve in-depth interviews, focus groups, and surveys to dig deeper into consumers' motivation and behaviour.

There is also a concern about social desirability bias in charitable giving research (Nancarrow, Brace, \& Wright, 2001; Lee \& Sargeant, 2011). Defined as "the need of subjects to obtain approval by responding in a culturally appropriate and acceptable manner" (Crowne \& 
Marlowe, 1960: 353 as cited in Lee \& Sargeant, 2011), social desirability bias in the case of OSL4D could lead lenders to claim they lend more than they actually do or to alter the real motivation for their lending. This study separated motivations to participate in OSL4D into extrinsic and intrinsic motivations where the results of the analysis were heavily weighted towards the intrinsic motivations. Lee and Sargeant (2011) found that when donors sought intrinsic benefit or psychological utility from their giving they were less likely to exhibit any social desirability bias. Additionally, these statements were voluntarily written by lenders when then joined Kiva without knowledge that these statements would be used for research purposes reducing the likelihood of a social desirability in their responses. Furthermore, while lender profiles are publically viewable, Kiva is not a social networking site and profile pages are not searchable. This reduces the likelihood that a profile page would be used for any social aims or to impress a viewer, thus further reducing the chances of social desirability bias.

The authors have proposed a definition of OSL4D and examined the motivations of those who participate in it. With the why consumers participate in OSL4D addressed, the next question is the how. Some initial work has begun with respect to lender preferences based on quantitative data provided by Kiva (Galak et al. 2010; Ly \& Mason, 2012). This work, while insightful, fails to address a number of important factors in the OSL4D process. One such factor is the role of the borrower's picture. The borrower picture is placed in a position of prominence on the borrower's page and shows the lender exactly who they will be lending to. What influence does the picture and various elements of the picture have on lender's choice? The effectiveness of positive and negative imagery in charity fundraising appeals for international development agencies has shown mixed results in previous studies (Dyck \& Coldevin, 1992; Radley \& Kennedy, 1997; Dogra, 2007). The borrower's story could be another important factor of how the lender makes 
their choice. It appears beneath the picture and could contain elements such as marital status of the borrower, number of children they are supporting, or other emotional appeals which do not appear in the quantitative data used in previous studies. As Kiva lenders claim to represent 217 countries (Kiva, 2012), questions around cultural influences on the lender's motivation and decision making process abound. How do national cultural influences, measured perhaps by Hofstede's dimensions, influence OSL4D behaviour? How does cultural distance between the lender and the borrower influence a lender's choice? Are there historical or economic ties between a lender and a borrower's country of residence? There are also elements related to online consumer behaviour that should be examined, such as the effect of a borrower's profile placed on the Kiva homepage, at the top of the Lend page, or the number of pages of loans a lender will click through before choosing a borrower to support. The authors call for further empirical studies involving OSL4D in order to refine the concept and to further inform both consumer behaviour and development practice. 


\section{REFERENCES}

Aaker, J., Chang, V., \& Jackley, J. (2010). Kiva and the Power of a Story. Stanford Business School, Case M-325.

Andreoni, J. (1990). Impure altruism and donations to public goods: a theory of warm-glow giving. The Economic Journal, 100(401), 464-477.

Assadi, D. \& Hudson, M. (2010). Marketing Mix of Online Social Lending Websites, Journal of Electronic Commerce in Organizations, 8(3), p.15-25

Auten, G. E., Sieg, H., \& Clotfelter, C. T. (2002). Charitable giving, income, and taxes: An analysis of panel data. The American Economic Review, 92(1), 371-382.

Azzi, C., and Ehrenberg, R. (1975). Household allocation of time and church attendance. The Journal of Political Economy, 83(1), 27-56.

Basil, D. (2007). Charitable Donations as a Reflection of National Values: An exploratory Comparison of Canada and the United States. Journal of Nonprofit \& Public Sector Marketing, $18(1), 1-19$

Basil, D., Ridgeway, N., \& Basil, M. (2006). Guilt Appeals: The Mediating Effect of Responsibility. Psychology and Marketing, 23(12), 1035-1054

Batson, CD. (1990). How social an animal? The human capacity for caring. American Psychologist, 45(March), 336-346

Bendapudi, N., Singh, S.N., \& Bendapudi, V. (1996). Enhancing helping behavior: an integrative framework for promotion planning. Journal of Marketing, 60(3), 33-54

Berelson, B. (1952), Content Analysis in Communications Research, Glencoe, IL: Free Press.

Bonbright, D., Kiryttopoulou, N., \& Iverson, L. (2008). Online Philanthropy Markets: from feel good giving to effective social investing? London: The Aspen Institute.

Burnett, J.J., \& Wood, VR. (1988). A proposed model of the donation decision process. Research in Consumer Behavior, 3, 1-47

Carlman, A. (2010). Development 2.0? The Case of Kiva.org and Online Social Lending for Development. Unpublished master's thesis, Stellenbosch University, South Africa

Coulter, R., Cotte, J., \& Lunt Moore, M. (1999). Believe It or Not: Persuasion, Manipulation, and Credibility of Guilt Appeals. Advances in Consumer Research, 26, 288-294 
Crowne, D.P. \& Marlowe, D. (1960). A new scale of social desirability independent of psychopathology. Journal of Consulting Psychology, 24, 349-354

Deci, E.L. (1975). Intrinsic Motivation, Plenum, New York

Deci, E.L. \& Ryan, R.M. (1985). Intrinsic Motivation and Self-Determination in Human Behaviour. Plenum, New York.

Dogra, N. (2007). 'Reading NGOs Visually' - Implications of visual images for NGO management. Journal of International Development, 19, 161-171

Drollinger, T. (2010). A Theoretical Examination of Giving and Volunteering Utilizing Resource Exchange Theory. Journal of Nonprofit \& Public Sector Marketing, 22, 55-66

Duncan, B. (2004). A theory of impact philanthropy. Journal of Public Economics, 88(9/10), 2159-2181

Dyck, E. \& Coldevin, G. (1992). Using Positive vs. Negative Photographs for Third-World Fund Raising. Journalism \& Mass Communication Quarterly, 69(3), 572-579

Essoussi, L., \& Zahaf, M. (2008). Decision making process of community organic food consumers: an exploratory study. Journal of Consumer Marketing, 25(2), 95-104

Flannery, M. (2007). Kiva and the Birth of Person-to-Person Microfinance. Innovations. Winter \& Spring, 31-56

Frey, B. \& Goette, L. (1999). Does Pay Motivate Volunteers?, Working Paper Series No.7. Zürich: Institute of Empirical Research in Economics.

Grayson, K., \& Rust, R. (2001). Inter-rater reliability assessment in content analysis. Journal of Consumer Psychology, 10(12), 71-73.

Gruen, R. \& Mendelsohn, G. (1986). Emotional Responses to Affective Displays in Others: The Distinction Between Empathy and Sympathy. Journal of Personality and Social Psychology, 51(3), 609-614

Guy, B.S., \& Patton, W.E. (1989). The Marketing of Altruistic Causes: Understanding Why People Help. Journal of Consumer Marketing, 6(1), 19-31

Harbaugh, W. (1998). What do donations buy? A model of philanthropy based on prestige and warm glow. Journal of Public Economics, 67(2), 269-284

Hrung, W.B. (2004). After-life consumption and charitable giving. American Journal of Economics and Sociology, 63(3), 731-745. 
Huhmann, B.A. \& Brotherton, T.P. (1997). A Content Analysis of Guilt Appeals in Popular Magazine Advertisements. Journal of Advertising, 26(2), 35-45.

Hulme, M. K., \& Wright, C. (2006). Internet Based Social Lending: past, present, and future. Social Futures Observatory, 1-115.

Iannaccone, L. (1998). Introduction to the economics of religion. Journal of Economic Literature, 36, 1465-1496.

Jas, P. (2000). A gift relationship? Charitable giving in theory and practice, NCVO, London.

Kassarjian, H.H. (1977). Content Analysis in Consumer Research. Journal of Consumer Research, 4 (1), 8-18.

Kiva (2010). About Kiva. Retrieved October 16, 2010 from http://www.kiva.org/about

Kiva (2012). Statistics. Retrieved February 22, 2012 from http://www.kiva.org/about/stats

Kolbe, R.H. \& Burnett, M.S. (1991). Content-Analysis Research: An Examination of Applications with Directives for Improving Research Reliability and Objectivity. Journal of Consumer Research, 18 (2), 243-50.

Kottasz, R. (2004). How should charitable organizations motivate young professionals to give philanthropically?. International Journal of Nonprofit \& Voluntary Sector Marketing, 9(1), 9-27

Landis, J. R., \& Koch, G.G. (1977). The measurement of observer agreement for categorical data. Biometrics, 33 (1), 159-174.

Lee, Z. \& Sargeant, A. (2011). Dealing with social desirability bias: an application to charitable giving. European Journal of Marketing, 45(5), 703-719

Lerner, M. (1975). The justice motive in social behavior. Journal of Social Issues, 31(3), 1-20

Meier, S. \& Stutzer, A. (2008). Is Volunteering Rewarding in Itself? Economica, 75(297), 39-59

Miller, DT. (1977). Altruism and threat to belief in a just world. Journal of Experimental Social Psychology, 13, 113-124

Morgan, R., \& Hunt, S. (1994). The Commitment-Trust Theory of Relationship Marketing, The Journal of Marketing, 58(3), 20-38

Nancarrow, C., Brace, I. \& Wright, L.T. (2001). 'Tell me lies, tell me sweet little lies': dealing with socially desirable responses in market research. The Marketing Review, 2, 55-69

Nijssen, E.J., \& Douglas, S. (2008). Consumer World-Mindedness, Social-Mindedness, and Store Image. Journal of International Marketing, 16(3), 84-107 
Pearce, P., \& Amato, P. (1980). A taxonomy of helping: A multidimensional scaling analysis. Social Psychological Quarterly, 43, 363-371.

Peloza, J., \& Hassay, D. (2007). A Typology of Charity Support Behaviors: Toward a Holistic View of Helping. Journal of Nonprofit \& Public Sector Marketing, 17(1/2), 135-151

Powers, T. \& Hopkins R. (2006). Altruism and Consumer Purchase Behavior. Journal of International Consumer Marketing, 19(1), 107-130

Prouteau, L. \& Wolff, F.C. (2004). Volunteer work and labour supply: theory and evidence. Mimeo, Faculte'des Sciences Economiques, Universite' de Nantes.

Radley, A. \& Kennedy, M. (1997). Picturing Need: Images of Overseas Aid and Interpretations of Cultural Difference. Culture \& Psychology, 3(4), 435-460

Randolph, W. (1995). Dynamic income, progressive taxes, and the timing of charitable contributions. Journal of Political Economy, 103(4), 709-738.

Ranganathan, S.K., and Henley, W.H. (1997). Determinants of charitable donation intentions: A structural equation model. International Journal of Nonprofit and Voluntary Sector Marketing, 13(1), p.1-11

Russell III, J. (2008). Charitable giving and the financial planner: theories, findings, and implications. Journal of Personal Finance, 6(4), 98-117

Ryan, R.M. \& Deci, E.L. (2000). Intrinsic and extrinsic motivations: classic definitions and new directions. Contemporary Educational Psychology, 25, 54-67

Sargeant, A., West, D., \& Ford, J. (2004). Does perception matter?: an empirical analysis of donor behaviour. Service Industries Journal, 24(6), 19-36.

Sargeant, A. \& Woodliffe, L., (2007a). Building Donor Loyalty: The Antecedents and Role of Commitment in the Context of Charity Giving, Journal of Nonprofit \& Public Sector Marketing, $18(2), 47-68$

Sargeant, A. \& Woodliffe, L., (2007b). Gift Giving: an interdisciplinary review. International Journal of Nonprofit and Voluntary Sector Marketing, 12(4), 275-307

Schneider, S., Loeber, S., Janßen, M., Roehrig, S., \& Solle, D. (2010). What prevents young adolescents from smoking? Self-reported motives of 12-15-year-old non-smokers. Health Policy, 95(1), 36-40

Sheth, J., Newman, B., \& Gross, B. (1991). Why We Buy What We Buy: A Theory of Consumption Values, Journal of Business Research, 22, p.159-170 
Sloane, S., Baillargeon, R., \& Premack, D. (2012). Do Infants Have a Sense of Fairness? Psychological Science, 23(2), 196-204

Small, D. \& Simonsohn, U. (2008). Friends of Victims: Personal Experience and Prosocial Behavior. Journal of Consumer Research, 35(October), 532-542

Smithson, M., \& Amato, P. (1982). An unstudied region of helping: An extension of the PearceAmato cognitive taxonomy. Social Psychological Quarterly, 45(2), 67-76.

Sokolowski, S.W. (1996). Show me the way to the worthy deed: towards a microstructural theory of volunteering and giving, Voluntas, 7(3), p.259-278

Statistics Canada. (2009). Caring Canadians, involved Canadians: highlights from the 2007 Canada Survey of Giving, Volunteering and Participating, Catalogue no. 71-542-XPE

Sulek, M. (2010). On the Classical Meaning of Philanthrôpía. Nonprofit and Voluntary Sector Quarterly, 39(3), p.385-408

Vallerand, R. \& Bissonnette, R. (1992). Intrinsic, extrinsic, and amotivational styles as predictors of behavior: A prospective study. Journal of Personality, 60(3), 599-620

Weick, K. (1984). Small Wins: Redefining the Scale of Social Problems. American Psychologist, 39(1), 40-49 
Figure 1: Model of Lender Behavior

\begin{tabular}{|c|c|c|c|}
\hline Needs & Motivations & $\begin{array}{c}\text { Charitable Giving } \\
\text { Alternatives }\end{array}$ & Decision Criteria \\
\hline $\begin{array}{l}\text { 1. Love for } \\
\text { Humanity } \\
\text { (need to express) } \\
\text { 2. Personal } \\
\text { Happiness } \\
\text { (need to obtain) }\end{array}$ & $\begin{array}{l}\text { 1. Altruism } \\
\text { 2. Desire to make a } \\
\text { difference } \\
\text { 3. Empathy } \\
\text { 4. Existential Guilt } \\
\text { 5. Religious } \\
\text { Commitment } \\
\text { 6. Sympathy } \\
\text { 7. Social justice } \\
\text { 8. Anticipatory Guilt } \\
\text { 9. Egoism } \\
\text { 10. Prestige } \\
\text { 11. Reactive Guilt } \\
\text { 12. Tax benefits }\end{array}$ & $\begin{array}{l}\text { 1. Sponsorship } \\
\text { Programs } \\
\text { 2. Traditional } \\
\text { Charities } \\
\text { 3. Socially } \\
\text { Responsible Shopping } \\
\text { (Investing) }\end{array}$ & $\begin{array}{l}\text { 1. Choice of Cause } \\
\text { a. Poverty Alleviation } \\
\text { b. Homeless } \\
\text { c. Refugees } \\
\text { d. Disease } \\
\text { e. Others } \\
\text { 2. Choice of Charity } \\
\text { a. Transparency } \\
\text { b. Feedback/ } \\
\text { Communication of Impact } \\
\text { c. Certification/ } \\
\text { Charity Rating } \\
\text { d. Overall Efficiency } \\
\text { 3. Choice of Borrower } \\
\text { a. Borrower's Country } \\
\text { b. Borrower's Gender } \\
\text { c. Borrower's Age } \\
\text { d. Borrower's Language } \\
\text {. Borrower's } \\
\text { Commercial Activity } \\
\text { f. Borrower's } \\
\text { Marital Status } \\
\text { g. Quality of the story } \\
\text { h. Borrower's } \\
\text { Number of Children } \\
\text { i. Borrower's Picture } \\
\text { j. Borrower's Name }\end{array}$ \\
\hline
\end{tabular}


Figure 2: Lender Value Proposition

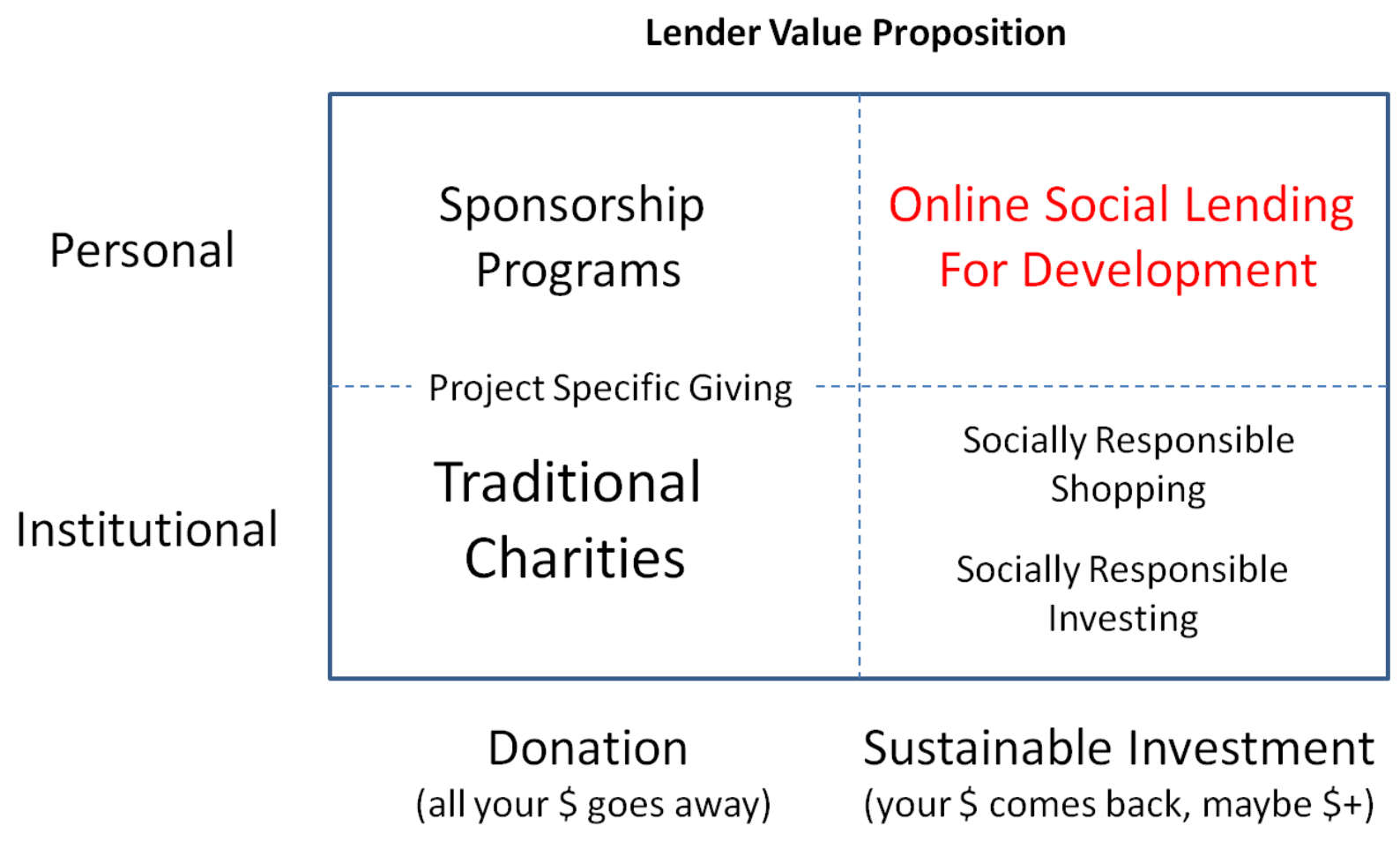

Source: Adapted from Aaker et al. 2010 
Figure 3: I loan because Word Cloud

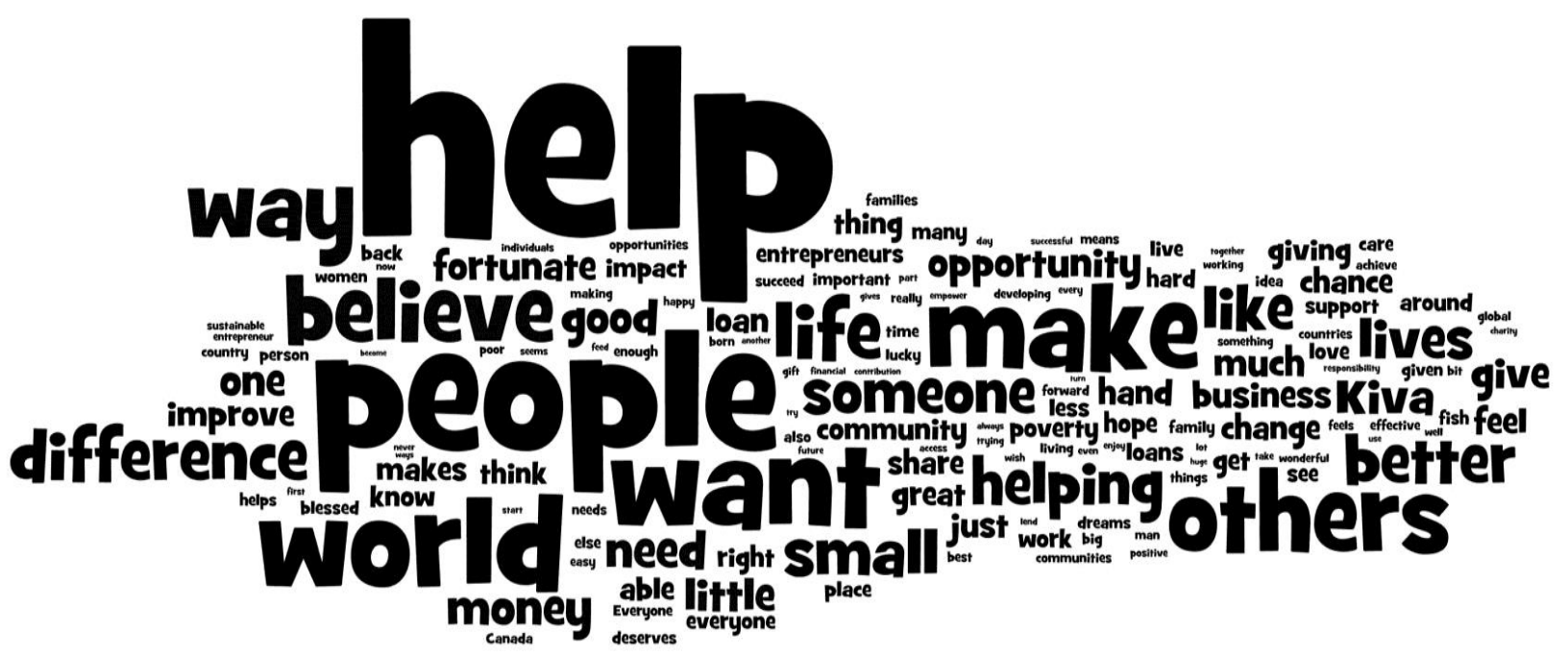

Source: Made with Wordle.net 
Figure 4: OSL4D Lender Motivation by OIT Taxonomy

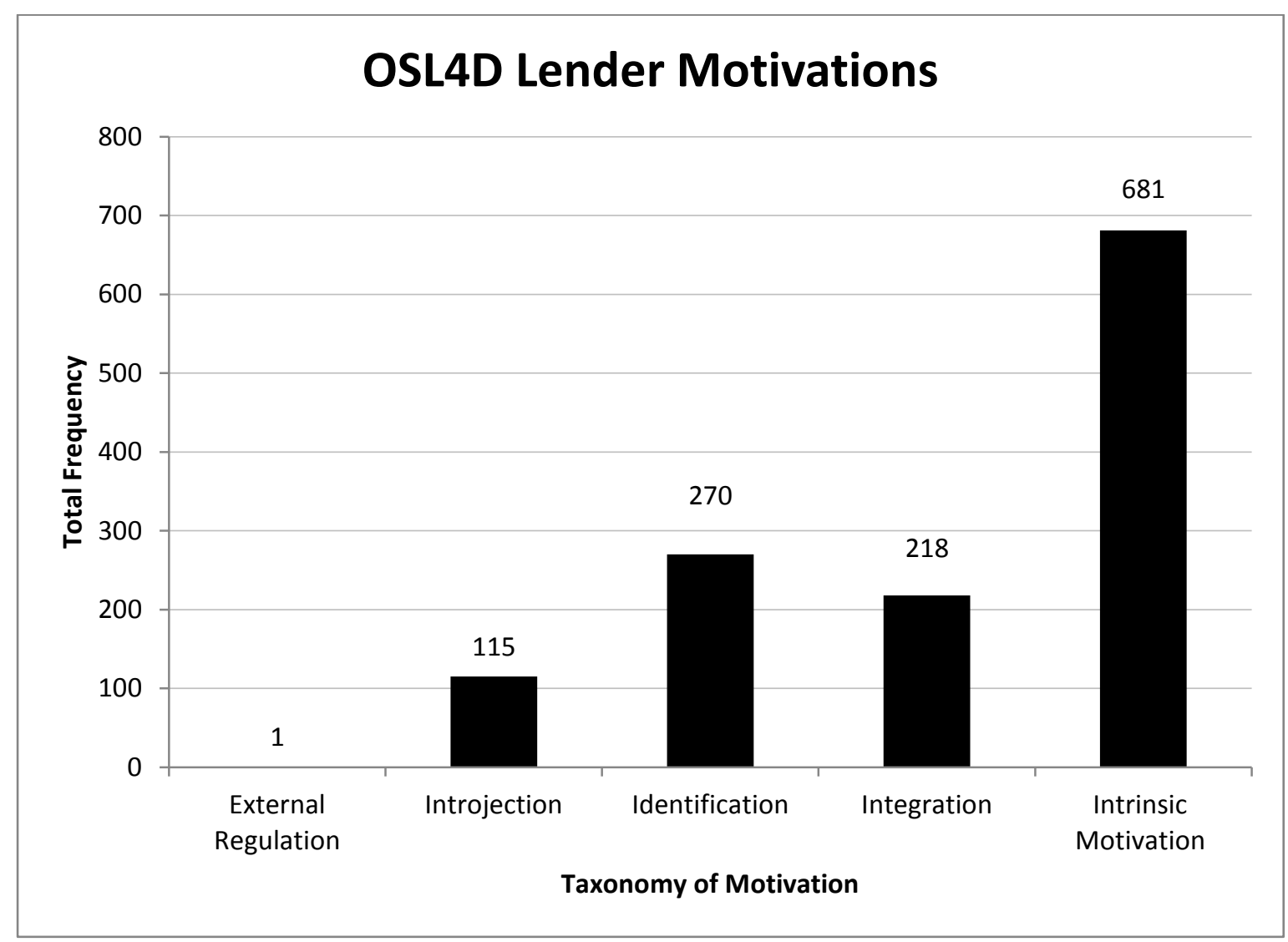


Table 1: Organismic Integration Theory (OIT) Taxonomy of Motivations

\begin{tabular}{|l|l|l|l|l|l|}
\hline \multirow{2}{*}{$\begin{array}{l}\text { Regulatory } \\
\text { Styles }\end{array}$} & \multicolumn{4}{|c|}{ Extrinsic Motivation } & $\begin{array}{l}\text { Intrinsic } \\
\text { Motivation }\end{array}$ \\
\cline { 2 - 6 } & $\begin{array}{l}\text { External } \\
\text { Regulation }\end{array}$ & Introjection & Identification & Integration & \\
\hline $\begin{array}{l}\text { Perceived } \\
\text { Locus of } \\
\text { Causality }\end{array}$ & External & $\begin{array}{l}\text { Somewhat } \\
\text { External }\end{array}$ & $\begin{array}{l}\text { Somewhat } \\
\text { Internal }\end{array}$ & Internal & Internal \\
\hline $\begin{array}{l}\text { Associated } \\
\text { Motives }\end{array}$ & - Tax Benefit & $\begin{array}{l}\text {-Egoism } \\
\text { - Anticipatory } \\
\text { Guilt } \\
\text { - Prestige }\end{array}$ & $\begin{array}{l}\text { - Sympathy } \\
\text { - Reactive guilt } \\
\text { - Social justice }\end{array}$ & $\begin{array}{l}\text { - Empathy } \\
\text { - Existential } \\
\text { Guilt } \\
\text { - Religious } \\
\text { Commitment }\end{array}$ & $\begin{array}{l}\text { - Altruism } \\
\text { - Desire to } \\
\text { make a } \\
\text { difference }\end{array}$ \\
\hline
\end{tabular}


Table 2: Needs and Motivations

\begin{tabular}{|c|c|c|}
\hline Needs & Love for Humanity & Personal Happiness \\
\hline \multirow{4}{*}{ Motivation } & Altruism & Anticipatory Guilt \\
\cline { 2 - 3 } & Desire to Make a Difference & Egoism \\
\cline { 2 - 3 } & Empathy & Prestige \\
\cline { 2 - 3 } & Existential Guilt & Reactive Guilt \\
\cline { 2 - 3 } & Religious Commitment & Tax Benefit \\
\cline { 2 - 3 } & Sympathy & \\
\cline { 2 - 3 } & Social Justice & \\
\hline
\end{tabular}


Table 3: Team Canada Profile

\begin{tabular}{|l|c|}
\hline Location & Canada \\
\hline Team URL & www.kiva.org/team/team_canada \\
\hline Number of Members & 3,120 \\
\hline Ranking - Team Size & $8^{\text {th }}$ largest in the world \\
\hline Number of "I loan because" statements & 1,299 \\
\hline Number of acceptable statements & 1,283 \\
\hline Coverage & $41 \%$ \\
\hline Total number of loans by members & 99,425 \\
\hline Total value of loans by members & $\$ 2,485,645$ \\
\hline Team in existence since & August, 2008 \\
\hline
\end{tabular}


Table 4: OSL4D Lender Motivations

\begin{tabular}{|l|c|}
\hline \multicolumn{1}{|c|}{ Motive } & Frequency \\
\hline Make a Difference & 442 \\
\hline Altruism & 239 \\
\hline Social Justice & 198 \\
\hline Guilt-Existential & 138 \\
\hline Egoism & 101 \\
\hline Sympathy & 71 \\
\hline Religious Commitment & 42 \\
\hline Empathy & 38 \\
\hline Guilt-Anticipatory & 7 \\
\hline Prestige & 5 \\
\hline Guilt - Reactive & 1 \\
\hline Tax Benefit & 1 \\
\hline
\end{tabular}

